\title{
Morphometric Analysis for Prioritization of Sub-watersheds of Mungeli Block Using a Remote Sensing GIS Technique
}

\author{
Manju Dhruw* and D. Khalkho \\ Department of Soil and Water Engineering, SVCAET \& RS. FAE, \\ IGKV, Raipur Chhattisgarh, India \\ *Corresponding author
}

\section{A B S T R A C T}

\begin{tabular}{l} 
Ke y w o r d s \\
Morphometric \\
analysis, \\
Watershed, GIS, \\
Prioritization, Arc \\
GIS \\
Article Info \\
\hline $\begin{array}{l}\text { Accepted: } \\
18 \text { May } 2020 \\
\text { Available Online: } \\
\text { 10 June } 2020\end{array}$ \\
\hline
\end{tabular}

\section{Keywords}

Morphometric analysis,

atershed, GIS Prioritization, Arc GIS
Land, water and soil are limited natural resources and their wide utilization with increasing population is a major area of concern. To mitigate the demand and supply gap between resources and ever increasing demand, it is of prime importance to conserve the natural resources with proper prioritization for its sustainable development. Morphometric analysis of a watershed provides a quantitative description of a drainage system. It is an important aspect of the watershed characterization. In this study, the morphometric analysis and prioritization of fourteen Sub-watersheds of watershed, situated in Mungeli block of Mungeli District Chhattisgarh State, India, was studied .comprises $978.345 \mathrm{~km}^{2}$ area and lies between $22^{\circ} 5,5.12^{\prime \prime} \mathrm{N}$ to $21^{\circ} 9^{\prime} 3.58^{\prime \prime} \mathrm{N}$ latitude and $81^{\circ} 31^{\prime} 8.36^{\prime \prime} \mathrm{E}$ to $81^{\circ}$ $78^{\prime} 9.32^{\prime \prime} \mathrm{E}$ longitude .The entire study region is divided into $14 \mathrm{sub}$-watersheds named as, 4G3F3b, 4G3F3c, 4G3F3d,4G3F3f, 4G3F3g, 4G3F3h, 4G3F3j, 4G3F3k, 4G3F3m, $4 \mathrm{G} 3 \mathrm{~F} 3 \mathrm{n}, 4 \mathrm{G} 3 \mathrm{~F} 3 \mathrm{p}, 4 \mathrm{G} 3 \mathrm{~F} 3 \mathrm{q}, 4 \mathrm{G} 3 \mathrm{~F} 3 \mathrm{r}$ and $4 \mathrm{G} 3 \mathrm{~F} 3 \mathrm{~s}$. The drainage density of sub-watersheds varies between 0.8 to $1.13 \mathrm{~km} / \mathrm{km}^{2}$ and low drainage density values of sub-watershed $4 \mathrm{G} 3 \mathrm{~F} 3 \mathrm{r}$ indicates that it has highly resistant, impermeable subsoil material with dense vegetative cover and low relief. The elongation ratio varies from 0.62 to 0.68 which indicates high relief and steep ground slope. The high value of circularity ratio for 4G3F3p sub-watershed (0.742) indicates the late maturity stage of topography. The compound parameter values are calculated and the sub-watershed with lowest compound weight is given highest priority. The sub-watershed 4G3F3f has a minimum compound parameter value of 4.6 is likely to be subjected to maximum soil erosion and susceptible to natural hazards. Hence it should be provided with immediate soil conservation measures.

\section{Introduction}

Land is a precious resource as it is the physical base of biomass on the earth. Conservation of such type of natural resources is important to mitigate the increasing demand of land and water resources. According to National Bureau of Soil Survey \& Land use Planning report (NBSS, 2005) about 146.82 million hectares area is reported to be suffering from various kinds of land degradation. In India, the 
increasing population is exerting enormous amount of pressure on available natural resources. The future of human being is closely associated with proper development and conservation of natural resources like land and water. Hence, sustainable development of natural resources is of prime importance. In view of the above, the development and management of land resources is an important weapon in country's war against poverty and food security. The watershed development programme has tremendous potential to render socioeconomic justice, attain self-reliance and balanced development (Pawar, 2003, Pawar and Panhalkar, 2011). The watershed development programme not only protects and conserves the environment, but also contribute to livelihood security Morphometry is the measurement and mathematical analysis of the configuration of the earth's surface, shape and dimension of its landforms (Agarwal, 1998; Obi Reddy et al., 2002). A major emphasis in geomorphology over the past several decades has been on the development of quantitative physiographic methods to describe the evolution and behaviour of surface drainage networks (Horton, 1945; Leopold and Maddock, 1953; Abrahams, 1984). Morphometric studies involve evaluation of streams through the measurement of various stream properties. Analysis of various drainage parameters namely ordering of the various streams and measurement of area of basin, perimeter of basin, length of drainage channels, drainage density (Dd), drainage frequency, bifurcation ratio $(\mathrm{Rb})$, texture ratio $(\mathrm{T})$ and circulatory ratio (Rc) (Kumar et al., 2000). Drainage characteristics of many river basins and sub basins in different parts of the globe have been studied using conventional methods (Horton, 1945; Strahler, 1957, 1964; Krishnamurthy et al., 1996). To evaluate and prioritize the basin for soil and water conservation, quantitative analysis of morphometric characteristics is of immense importance. Morphometric analysis of a watershed provides a quantitative description of the drainage system which is an important aspect of the characterization of watersheds (Strahler, 1964). Various scholars have carried out morphometric analysis of river basins by using RS and GIS techniques. Shrimali et al., (2001) have worked on Sukhana lake catchment in the Shiwalik hills for the delineation and prioritization of soil erosion areas by GIS and remote sensing. Nooka et al., (2005) have carried out study on check dam positioning by prioritization of microwatersheds using the sediment yield index (SYI) model and morphometric analysis using GIS. The objective of the present study is to prioritize the Hiranyakeshi basin on the basis of morphometric analysis for watershed development.

\section{Study region}

The region selected for present study is Watershed of Mungeli block of Mungeli District Chhattisgarh. It comprises an area of $978.345 \mathrm{~km}^{2}$ and lies between $22^{\circ} 5^{\prime} 5.12^{\prime \prime} \mathrm{N}$ to $21^{\circ} 9^{\prime} 3.58^{\prime \prime} \mathrm{N}$ latitude and $81^{\circ} 31^{\prime} 8.36^{\prime \prime} \mathrm{E}$ to $81^{\circ} 78^{\prime} 9.32^{\prime}$ ' E longitude.

\section{Materials and Methods}

This work is basically based on morphometric analysis of Mungeli watershed to prioritize the sub-watershed for development. To assess the morphometric conditions, SRTM data (90 mresolution) and topographical maps (1: 50000) are used. At first, Mungeli watershed was delineated with the help of ARCSWAT software. Inlet and outlet are defined to demarcate Mungeli watershed. Sub-basins are also demarcated by using the same software to carry out the sub-basinwise morphometric analysis. Figure 3 shows the sub-basin map of Mungeli watershed. 
Fourteen sub-basins are identified for further analysis. Direct measurements of geometric characteristics (e.g., area and perimeter of the basin, length and number of streams) were automatically obtained from GIS software. Toposheets (Survey of India) were mosaiced to subset the study region. The subset image is geometrically corrected through the process of rectification. Strahler's, Horton's and Schumm's methods have been employed to assess the fluvial characteristics of the study region. Each morphometric characteristic is considered as a single parameter and knowledge based weightage has been assigned by considering its role in soil erosion. Each parameter has given a rank as per morphometric result.

For linear aspect, high weightage has been given for high values and aerial aspect is assigned low weightage for high values. The compound parameter values are calculated and the sub-watershed with lowest compound weight has been given highest priority. The final priority classification has been given into three major classes i.e. High priority, Medium priority and Low priority. The high priority indicates need of reclamation process and action plan for soil conservation.

\section{Results and Discussion}

Sub-watershed basin has been divided into 14 sub-basin from 4G3F3b to 4G3F3s (Fig. 3), ranging in geographical area $978.345 \mathrm{~km}^{2}$. These sub-basins have taken up for prioritization based on morphometric analysis. Drainage network is a significant indicator of the process of landform development in a geographical unit. Horton $(1932,1945)$ stated that a drainage basin as an ideal unit for understanding the geomorphological and hydrological processes and for evaluating the runoff pattern of the streams.

\section{Linear aspect}

Linear aspects of channel system are stream order $(\mathrm{U})$, stream length $\left(\mathrm{L}_{\mathrm{u}}\right)$ and stream frequency $\left(F_{s}\right)$.

\section{Stream order $(\mathbf{U})$}

The smallest recognizable stream is called as first order and these channels normally flow during wet season (Chow et al., 1988). The first order streams do not have any tributary. A second order stream forms when two first order streams join and a third order when two second order streams are joined and so on (Strahler, 1964). Where a channel of lower order joins a channel of higher order, the channel downstream preserves the higher of the two orders and the order of the river basin is the order of the stream draining its outlet, the highest stream order in the basin (Chow et al, 1988). Order wise stream number is counted and listed. The number of stream segments decreases as the stream order increases. It follows Horton's law of stream ordering. Watershed has 4 order stream. Hence these sub-basins have got high weightage for further analysis.

\section{Stream length $\left(\mathrm{L}_{\mathbf{u}}\right)$}

The stream lengths of the various segments are measured with the help of GIS software. Stream length was computed on the basis of law proposed by Horton. The total stream length decreases with increasing stream order. Accordingly sub-basin 4G3F3q has the highest length of first order stream that is around $126.18 \mathrm{~km}$. and the $4^{\text {th }}$ order stream length is only.

\section{Bifurcation ratio $(\mathbf{R b})$}

The bifurcation ratio is the ratio of the number of stream segments of given order to the number of segments of next higher order. 
Bifurcation ratio is an index of relief and dissection (Horton, 1945). Bifurcation ratio for different sub-watersheds of the study area has been calculated. It is well demonstrated that bifurcation ratio shows a small range of variation for different regions or for different environment except where geological control dominates (Strahler, 1950). The mean bifurcation ratio of all orders, varies from 2.57 to 5.72 .

\section{Aerial aspects}

Aerial aspects include form factor, elongation ratio, stream frequency, drainage density and circularity ratio. The result of this analysis are summarized in Table 1

\section{Form factor $\left(\mathbf{R}_{\mathbf{f}}\right)$}

The ratio of the basin area to the square of basin length is called the form factor. It is a dimensionless property and is used as a quantitative expression of the shape of basin form. The form factor of sub-basins varies between 0.303 to 0.364 .

\section{Elongation ratio $\left(\mathbf{R}_{\mathbf{e}}\right)$}

Schumm (1956) defined elongated ratio as the ratio of diameter of the circle of the same area in the basin to the maximum basin length. The elongation ratio for all watershed also varies from 0.62 to 0.66 which indicates high relief and steep ground slope.

Table.1 Prioritization of sub-watershed of the study area

\begin{tabular}{|c|c|c|c|c|c|c|c|c|c|c|c|c|c|}
\hline \multirow[b]{3}{*}{$\begin{array}{l}\text { GRID } \\
\text { CODE }\end{array}$} & \multicolumn{13}{|c|}{ Morphometric Parameters } \\
\hline & \multicolumn{6}{|c|}{ Linear Parameters } & \multicolumn{7}{|c|}{ Shape Parameters } \\
\hline & $\begin{array}{c}\text { Sub } \\
\text { Watershed }\end{array}$ & $\mathrm{Rb}$ & $\mathrm{Dd}$ & $\mathrm{Fu}$ & Lo & $\mathrm{T}$ & $\mathrm{Rc}$ & $\mathrm{Rf}$ & Bs & $\operatorname{Re}$ & $\mathrm{Cc}$ & $\mathrm{Cp}$ & $\begin{array}{c}\text { Prioritized } \\
\text { Ranks }\end{array}$ \\
\hline 1 & 4G3F3b & 3 & 6 & 7 & 5 & 3 & 13 & 3 & 10 & 3 & 2 & 5.5 & 4 \\
\hline 2 & $4 \mathrm{G} 3 \mathrm{~F} 3 \mathrm{c}$ & 8 & 4 & 3 & 3 & 6 & 5 & 3 & 8 & 3 & 10 & 5.3 & 3 \\
\hline 3 & 4G3F3d & 14 & 2 & 1 & 2 & 10 & 4 & 5 & 1 & 6 & 11 & 5.6 & 5 \\
\hline 4 & 4G3F3f & 11 & 14 & 12 & 11 & 12 & 8 & 3 & 11 & 3 & 7 & 9.2 & 13 \\
\hline 5 & 4G3F3g & 9 & 7 & 8 & 6 & 8 & 10 & 3 & 5 & 4 & 5 & 6.5 & 8 \\
\hline 6 & 4G3F3h & 4 & 13 & 10 & 10 & 5 & 11 & 2 & 12 & 2 & 4 & 7.3 & 10 \\
\hline 7 & 4G3F3j & 13 & 1 & 4 & 1 & 9 & 3 & 3 & 7 & 4 & 12 & 5.7 & 6 \\
\hline 8 & 4G3F3k & 6 & 3 & 3 & 2 & 2 & 6 & 1 & 13 & 1 & 9 & 4.6 & 1 \\
\hline 9 & 4G3F3m & 12 & 5 & 2 & 4 & 1 & 14 & 4 & 4 & 4 & 1 & 5.1 & 2 \\
\hline 10 & 4G3F3n & 10 & 12 & 10 & 9 & 11 & 7 & 3 & 6 & 4 & 8 & 8 & 12 \\
\hline 11 & 4G3F3p & 1 & 9 & 11 & 7 & 7 & 9 & 3 & 10 & 3 & 6 & 6.6 & 9 \\
\hline 12 & $4 \mathrm{G} 3 \mathrm{~F} 3 \mathrm{q}$ & 5 & 11 & 9 & 9 & 14 & 2 & 4 & 2 & 5 & 13 & 7.4 & 11 \\
\hline 13 & $4 \mathrm{G} 3 \mathrm{~F} 3 \mathrm{r}$ & 2 & 10 & 6 & 8 & 13 & 1 & 4 & 3 & 5 & 14 & 6.6 & 9 \\
\hline 14 & 4G3F3s & 7 & 8 & 5 & 6 & 4 & 12 & 3 & 9 & 3 & 3 & 6 & 7 \\
\hline
\end{tabular}


Fig.1 Location map of study region

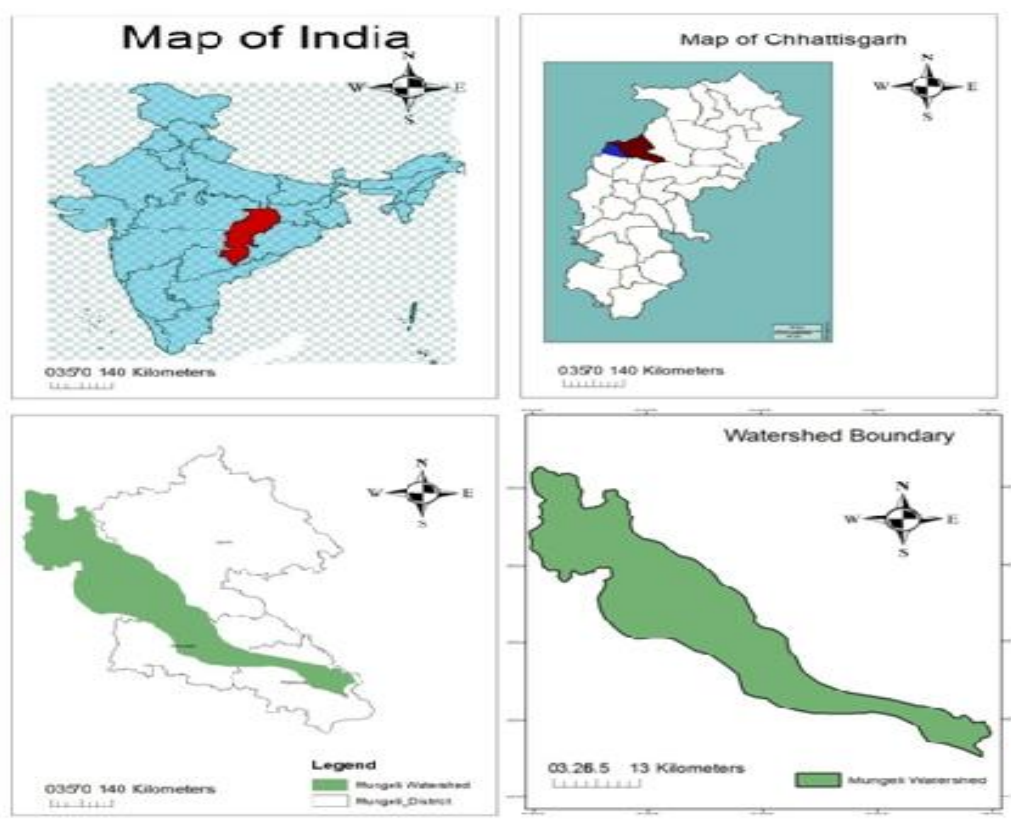

Fig.2 Flow chart of methodology

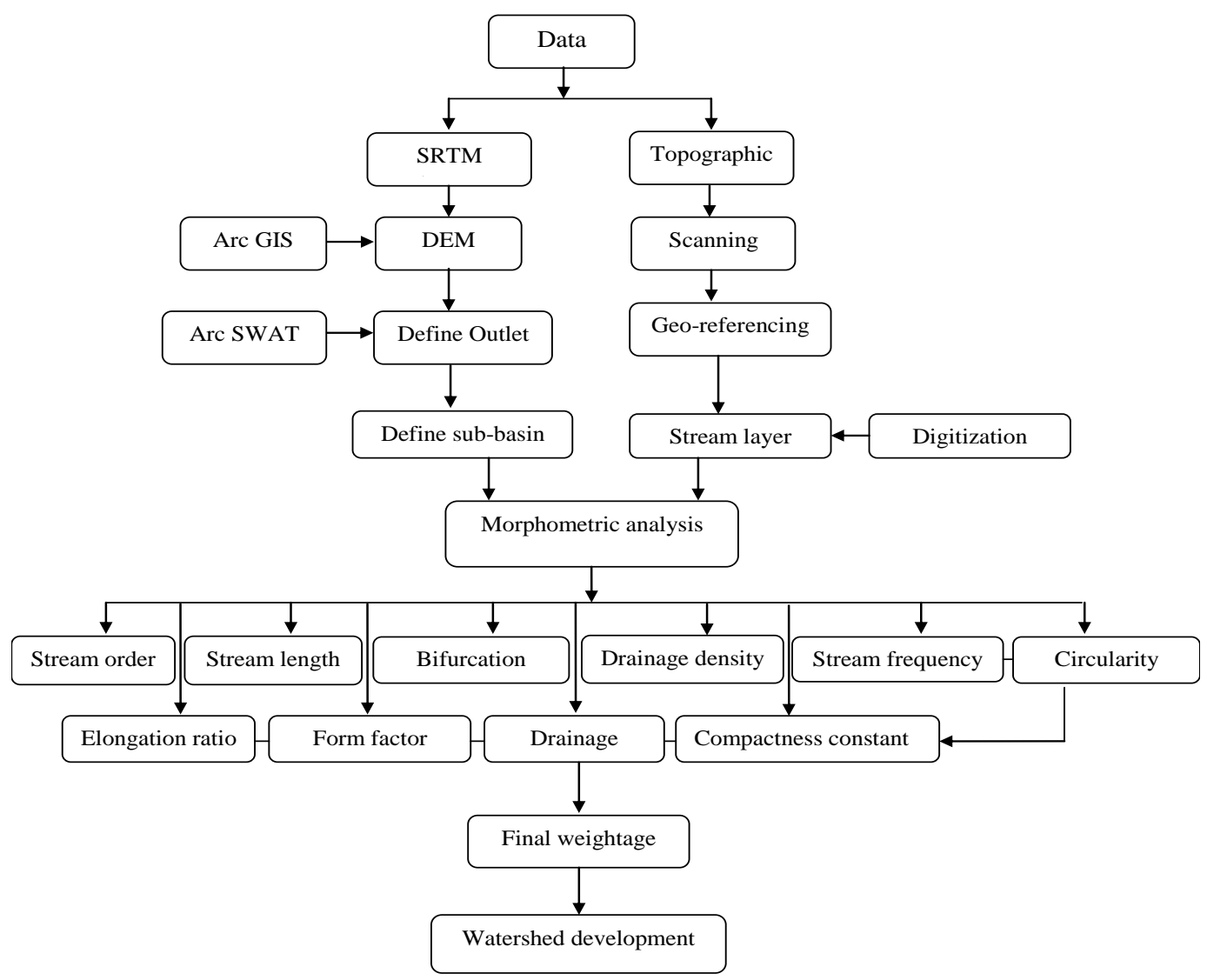


Fig.3 Sub-watershed of the study area

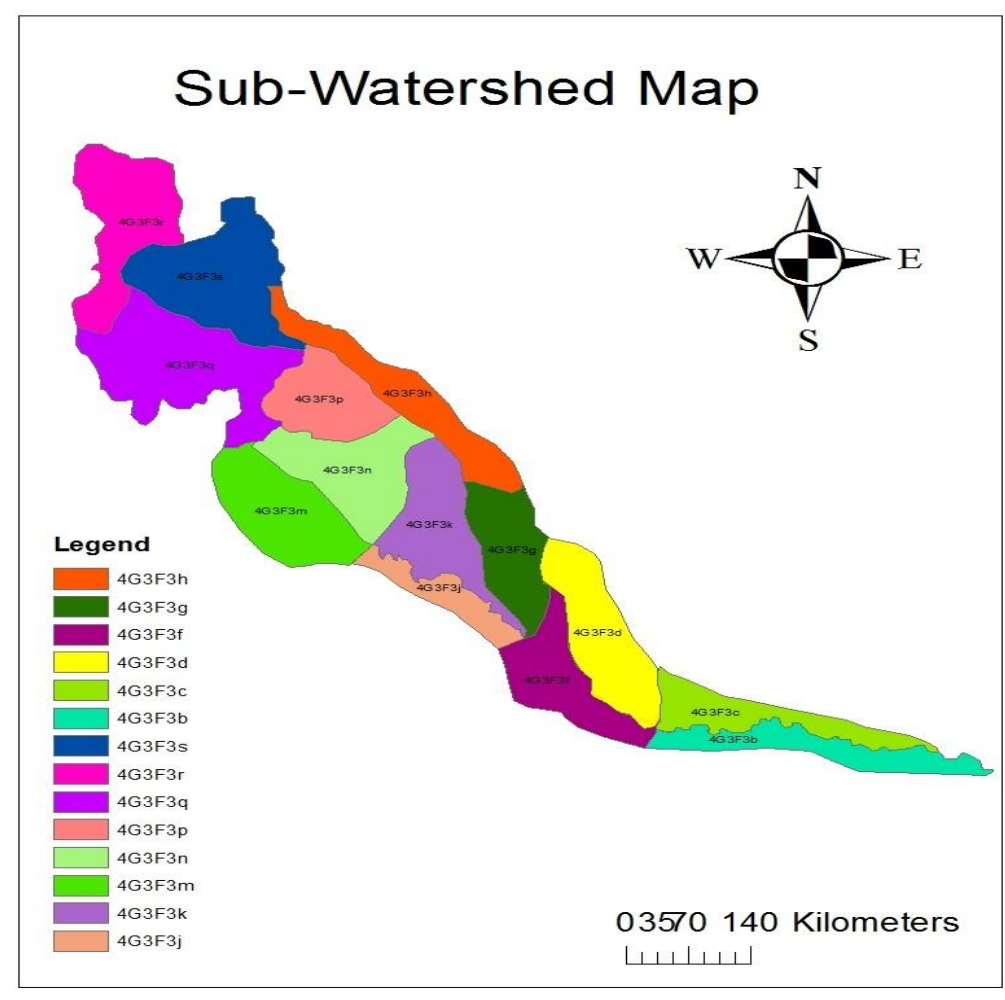

Fig.4 Drainage map of the study area

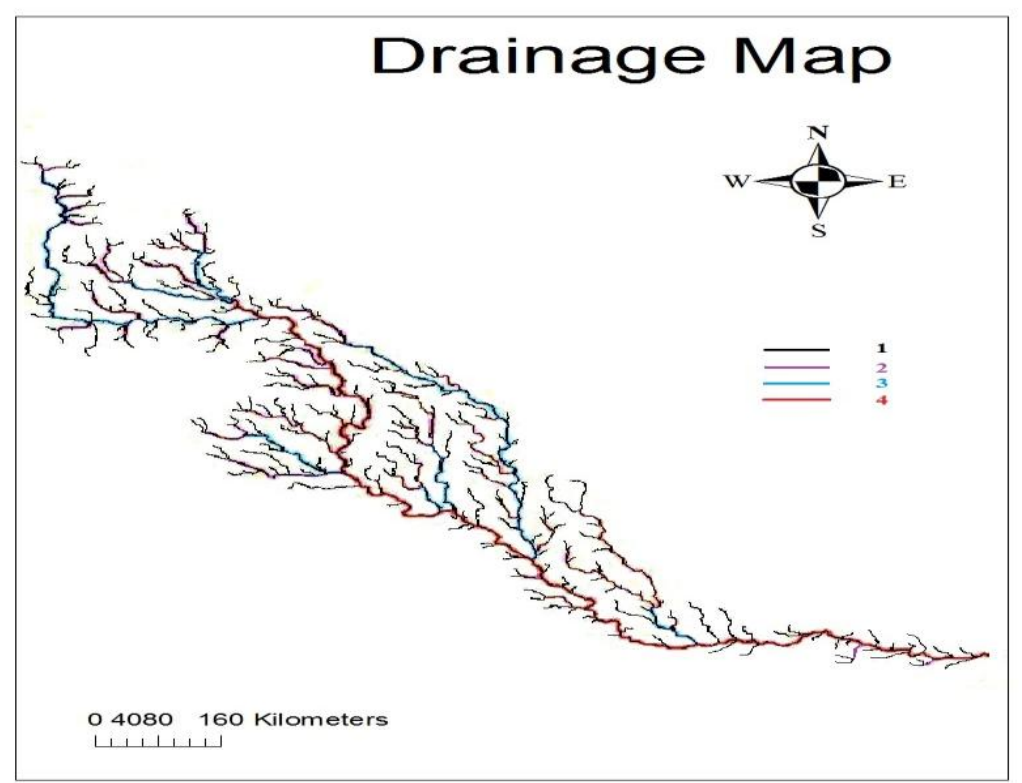


Fig.5 Prioritized sub-watershed of the study area

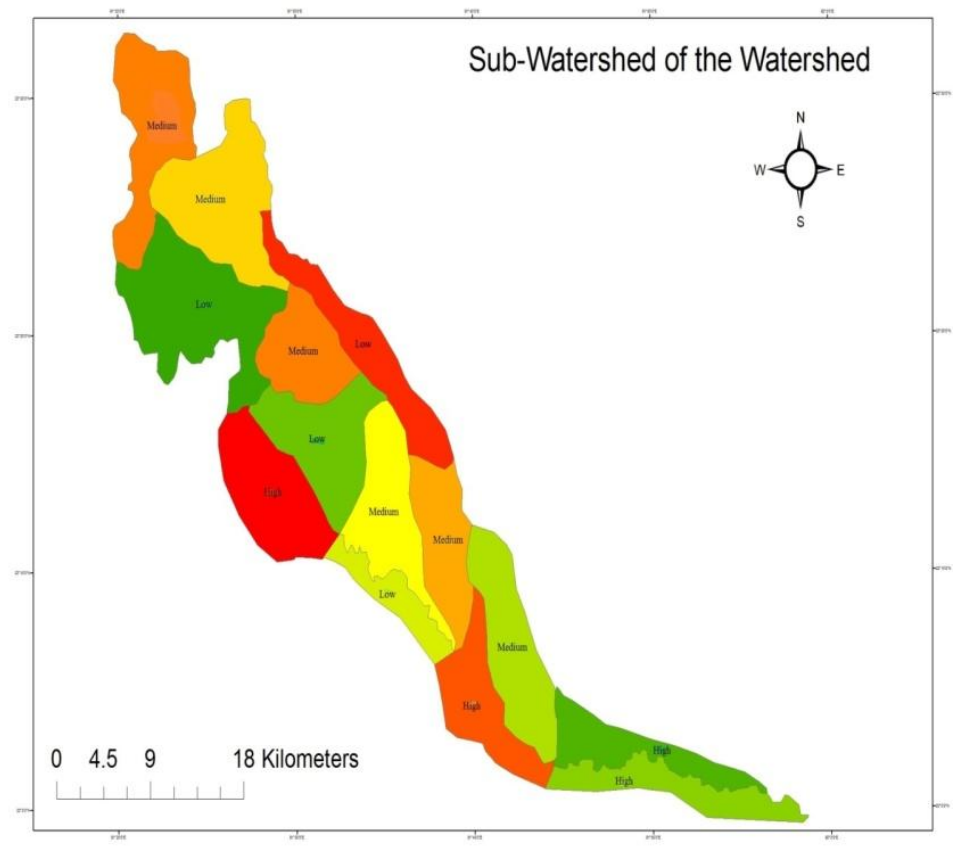

\section{Circulatory ratio $\left(\mathbf{R}_{\mathbf{c}}\right)$}

Circularity ratio is the ratio of the basin area to the area of a circle having the same circumference perimeter as the basin, which is dimensionless and expresses the degree of circularity of the basin (Miller, 1953). It is influenced by the length and frequency of the streams, geological structures, land use / land cover, climate, relief and slope of the watershed. In the watershed the circulatory ratio varies from 0.179 to 0.742 which shows the sub-watersheds are almost elongated.. This anomaly is due to diversity of slope, relief and structural conditions in the subwatersheds.

\section{Stream frequency $\left(F_{u}\right)$}

The stream frequency is defined as the total number of stream segment of all order per unit area (Horton, 1932). The stream frequency varies from basin to basin. Stream frequency ranges from 0.31 to 0.79 .

\section{Drainage density (Dd)}

Horton has introduced drainage density (Dd) as an expression to indicate the closeness of spacing of channels. The significance of drainage density is recognized as a factor determining the time travel by water (Schumm, 1956). In the present study, drainage density varies from 0.53 to 3.18 . It has been observed that low drainage density is more likely to occur in regions of high permeable subsoil material under dense vegetative cover while high drainage density is observed in regions of weak or impermeable sub-surface materials, sparse vegetation and high mountain relief By considering the influence of drainage density on soil erosion, the weights are assigned to each sub-basin.

\section{Watershed prioritization}

The morphometric parameters like drainage density, bifurcation ratio, stream frequency, elongation ratio, form factor can be termed as 
erosion risk assessment parameters and have been used to prioritize watershed (Biswas, et al., 1999). The linear aspects have the direct relationship with soil erosion. Hence, the parameter of higher value indicates the possibility of soil erosion.

\section{Conclusion}

The Morphometric characteristics of different sub-watersheds indicate their relative characteristics with respect to hydrologic response of the watershed. It has been observed that drainage morphometry derived from various methods fallows standard rules. Result of prioritization of sub-watershed shows that sub-watershed 4G3F3f comes under Mungeli block of Mungeli district so more susceptible to soil erosion as per morphometric analysis. Therefore, immediate attention towards soil observation measures is required in these sub-watersheds to preserve the land from future erosion and natural hazards.

\section{References}

Abrahams, A. D. (1984), Channel Networks: A Geomorphological Perspective, Water Resources. 20, pp 161-168.

Agrawal, C. S. (1998), Study of Drainage Pattern through aerial data in Navgarh area of Varanasi district, U.P., Journal. Indian Society of Remote Sensing. 26, pp 169-175.

Biswas, S., S. Sudhakar, and Desai V.R. (1999), Prioritisation of subwatersheds based on morphometric analysis of drainage basin: A Remote Sensing and GIS approach, Journal of Indian Society of Remote Sensing, 27(3), Pp. 155-166.

Chow, V.T. Maidment D.R. and Mayse W. (1988), Applied Hydrology, New York, McGraw Hill.

Horton, R.E. (1932), Drainage basin characteristics. Trans. Am. Geophys.
Union 13, pp 350-360.

Horton, R.E. (1945), Erosional development of stream and their drainage basin. Hydrogeological approach to quantitative morphology, Bulleting of Geological Society of America, 56, pp 275-370.

Krishnamurthy, J. Srinivas G., Jayaram V. and Chandrasekhar M.G. (1996), Influence of rock types and influence in development of drainage network in typical hardrock terrain. ITC. 3(4), pp 252-259.

Kumar, R., Lohani A. K., R. K. Nema and Singh R.D. (2000), Evaluation of Geomorphological characteristics of catchment using GIS. GIS India, 9(3), pp 13-17.

Leopold, L.B. and Maddock, T. (1953), The hydraulic geometry of stream channels and some physiographic implications, USGS Professional paper, 252, pp. 157.

Miller, V. C. (1953), A quantitative geomorphic study of drainage basin characteristics in the clinch mountain area, Technical report 3, Department of Geology, Columbia University.

Nooka R., K., Y.K. Srivastava., V. VenkateshwaraRoa, E. Amminedu and Murthy K.S.R. (2005), Check dam positioning by prioritization of microwatersheds Using SYI model and morphometric analysis - Remote sensing and GIS perspective, Journal of the Indian Society of Remote Sensing, 33(1), pp 25-28.

National Bureau of Soil Survey and Land Use Planning (NBSSLUP), (2005), Annual Report.

Obi Reddy, G.E., Maji A.K., Gajbhiye K.S. (2002), GIS for Morphometric Analysis of drainage basins, GIS India, 4, pp 914.

Panhalkar, S.S. and Pawar, C.T. (2011), Watershed Development Prioritization 
by applying WERM model and GIS techniques in Vedganga Basin (INDIA), ARPN Journal of Agriculture and Biological Science, pp 38-44.

Pawar, C.T. (2003), Assessment of watershed Development Programme: A Micro Level Imperial Analysis, Transactions, Institute of Indian Geographers, 25, pp 85-93.

Rajora R. (1998), Integrated Watershed Management: A Field Manual for Equitable, Productive \& Sustainable Development, Rawat Publications, Jaipur\& New Delhi.

Schumm, S. A. (1956), Evolution of drainage systems and slopes in Badlands at Perth Amboy, New Jersey. Geological Society of America, Bulletin, 67, pp 597-646.

Shrimali, S.S., Agarwal, S.P. and Samra J.S.
(2001), Prioritizing Erosion Prone areas in hills using Remote Sensing and GIS: A case study of Sukhna Lake Catchment, North India, Journal of Applied Geology, 3(1), pp 54-60.

Strahler, A.N., (1950), Equilibrium theory of erosional slopes approached by frequency distribution analyses American Journal of Science, v. 248, pp 673-696, 800-814.

Strahler, A.N. (1957), Quantitative Analysis of American Geomorphology Transactions, American Geophysical Union v. 38, pp 913-920.

Strahler, A.N. (1964), Quantitative Geomorphology of Drainage basins and channel networks. In V. T. Chow (Ed.) New York: McGraw Hill., Handbook of Applied Hydrology. Pp. 4, 39-4 and 76.

\section{How to cite this article:}

Manju Dhruw and Khalkho, D. 2020. Morphometric Analysis for Prioritization of Subwatersheds of Mungeli Block Using a Remote Sensing GIS Technique. Int.J.Curr.Microbiol.App.Sci. 9(06): 823-831. doi: https://doi.org/10.20546/ijcmas.2020.906.105 